\title{
POLA PENANGANAN PERILAKU BULLYING PADA SEKOLAH DASAR
}

\author{
Zulkifli Mansyur \\ Institut Agama Islam Negeri Manado \\ Zulkifli.mansyur@iain-manado.ac.id
}

\begin{abstract}
This study aims to look at bullying behavior that occurs in elementary schools and how the pattern of handling it by the parties involved in it. This study uses a descriptive quantitative approach. Each variable uses a measuring instrument in the form of a scale made for each variable. The age level and background of the subject will also be the limitations that will be carried out in taking information. This study involved 75 students who were sampled from grades 4 to 6. Bullying behavior that occurred in elementary schools was still dominated by physical bullying (48.56\%), followed by verbal bullying (26.28\%), ostracism (12.10\%), cyberbullying (5.2\%), and sexual harassment (7.05\%). Bullying behavior is only considered normal delinquent behavior so that no serious action is taken by the school, especially teachers so that there is no specific handling of bullying
\end{abstract}

Keywords: Bullying, Elementary school

\begin{abstract}
ABSTRAK
Penelitian ini bertujuan untuk melihat perilaku bullying yang terjadi di sekolah dasar dan bagaimana pola penanganannya oleh pihak yang terkait didalamnya. Penelitian ini menggunakan pendekatan kuantitatif deskriptif. Masing-masing variabel menggunakan alat ukur berupa skala yang dibuat untuk masing-masing variabel. Tingkatan umur dan latar belakang subjek juga akan menjadi batasan-batasan yang akan dilakukan dalam pengambilan keterangan. Penelitian ini melibatkan 75 orang siswa yang di ambil sampel dari kelas 4 sampai 6. Perilaku perundungan yang terjadi pada sekolah dasar masih di dominasi oleh perundungan fisik $(48,56 \%)$, kemudian di ikuti perundungan verbal $(26,28 \%)$, tindakan pengucilan $(12,10 \%)$, perundungan di dunia maya $(5,2 \%)$ dan penindasan seksual $(7,05 \%)$. Perilaku perundungan hanya di anggap perilaku kenakalan biasa saja sehingga tidak ada tindakan serius yang di ambil oleh pihak sekolah khususnya guru sehingga tidak ada penanganan yang spesifik tentang perundungan
\end{abstract}

Kata Kunci : Bullying, Sekolah dasar

\section{PENDAHULUAN}

Perkembangan manusia merupakan proses yang telah melewati berbagai evolusi dari waktu ke waktu. Perilaku yang diadopsi oleh setiap manusia akan menurun, entah melalui proses gen keturunan ataupun melalui adaptasi lingkungan yang dihadapi oleh individu tersebut. Perilaku-perilaku yang di lakukan dalam melakukan aktifitas sehari-hari tidak terlepas dari bawaan yang 
ada tersebut. Era modern yang hadir dengan segala percepatan informasi, aktifitas dan yang lainnya menjadikan beragam perilaku yang hadir. Dengan terbukanya informasi dari segala penjuru dunia, semua orang akan dapat dengan mudah mengakses informasi dari belahan bumi lainnya. Budaya, etika, pergaulan dan bahkan bahasa akan dapat dipelajari dengan mudah sekalipun terpisah samudra yang sangat luas.

Pendidikan yang hadir di tengahtengah era digital mau tidak mau sangat terpengaruhi dengan adanya kemajuan informasi yang sangat cepat. Segala kebutuhan baik dari sisi kurikulum, kapasitas keilmuan pendidik, sarana prasarana dan sumber belajar di sesuaikan agar tidak jauh tertinggal dan sesuai dengan kebutuhan masyarakat yang ada sekarang. Menilik pengaruhnya pada dunia pendidikan, Permasalahan yang hadir di saat sekarang sangat beragam dan kompeks, dan hal itu sangat dipengaruhi dengan kemajuan era yang hadir di tengah-tengah masyarakat. Konsumsi masyarakat akan budaya dan norma tidak lagi terkurung pada budaya sekitar melainkan dipengaruhi dari budaya lain yang itu semuanya dapat di akses melalui kecanggihan teknologi.
Kekerasan merupakan potongan kecil dari kompleksnya permasalahan dalam dunia pendidikan yang hadir. Menurut Baron dan Byrne (1994) bahwa perilaku agresif adalah perilaku individu yang memiliki tujuan untuk melukai dan mencelakakan seseorang baik direncanakan ataupun tidak dan dampak terburuk bahkan sampai membunuh.. Tindakan yang kurang terpuji sangat sering terjadi di dalam dunia pendidikan khususnya dalam lingkungan sekolah. Perilaku bullying atau sering disebut perundungan adalah tindakan yang tidak lagi bisa dianggap sebagai permasalahan biasa-biasa saja karena dampak dan efeknya sangat buruk, khususnya pada perkembangan peserta didik.

Istilah bullyiing atau bully berasal dari bahasa Inggris yang bermaksud mengertak atau menindas. Namun, istilah menggertak dan menindas tidak sesuai digunakan sebagai padanan kata bullying karena tidak mencakup keseluruhan maksud dari istilah bullying. Istilah yang paling tepat untuk istilah bullying dalam bahasa Indonesia adalah "perisakan”,yang berasal dari kata "risak" yang bermakna mengusik atau mengganggu secara terus-menerus dengan berbagai olok-olokan. Namun, 
Menteri Pendidikan dan Kebudayaan pada saat itu, Anies Baswedan lebih cendrung menggunakan kata "perundungan" atau "rundung" bagi padanan istilah bullying.

Perkataan perundungan atau rundung dapat mewakili istilah bullying yang bermakna mengganggu korbannya atau mengusik secara terus-menerus seperti melakukan intimidasi, penghinaan, pemalakkan, pemukulan, penindas atau penganggu orang lain yang lebih lemah sehingga korban terlukan atau depresi. Namun, kedua istilah tersebut yaitu "perisakan" atau "perundungan" belum begitu dikenal bahkan media cetak, media elektronik dan berbagai artikel ilmiah masih menggunakan istilah bullying atau bully dalam menyebutkan kekerasan di dunia pendidikan. Karena itu, dalam tulisan kali ini, akan digunakan istilah perundungan untuk menyebutkan tindakan bullying dalam dunia pendidikan

Tindakan perundungan terkadang telah menjadi tradisi dalam dunia pendidikan di Indonesia khususnya dapat terlihat pada saat dimulainya kegiatan pembelajaran di sekolah ataupun di universitas-universitas. Orientasi yang seharusnya menjadi ajang untuk pengenalan nilai-nilai budaya akademik seringkali ternodai dengan adanya bumbu-bumbu tindakan kekerasan dengan dalih untuk menegakkan kedisiplinan, membentuk karakter dan untuk mempererat hubungan antara senior dan junior. Namun yang terjadi seringkali bertolak belakang dengan yang di inginkan dimana antara senior dan junior mnejadi tidak harmonis dikarenakan ajang orientasi dijadikan sebagai wadah untuk meluapkan superioritas dari para senior dengan kekerkasan, permusuhan, kebencian yang dimana pelakunya mewarisi dari tradisi masa silam generasi terdahulu.

Bullying atau perundungan sering di temukan hampir di setiap lapisan masyarakat, dan itu tidak terlepas pada tingkatan umur dan lingkungan masyarakatnya. Perundungan tidak lagi hanya terjadi pada usia remaja akhir dan dewasa, namun telah sampai pada tahap yang sudah sangat menghawatirkan. Sekolah dasar yang awalnya adalah tahap dimana mulainya pendidikan norma dan etika, kini telah mulai disusupi perilaku perundungan tersebut. Dampaknya akan sangat beragam, mulai dari depresi, menjadi tertutup dengan orang sekitar dan parahnya adalah berujung pada kematian

Indonesia merupakan Negara yang memiliki kasus perundungan yang cukup 
banyak. Kasus kekerasan pada anak yang terjadi di Indonesia setiap tahun semakin meningkat statistiknya. Menurut laporan KPAI sejak tahun 2011 sampai 2014, jumlah kasus perundungan sebanyak 369 kasus. Namun pada 2015, kasus perundungan naik menadi 478 kasus. Di tahun 2016 jumlah kasus terkait perundungan berkurang menjadi 328 kasus. Pada tahun 2018 sampai pada bulan mei, telah terjadi 161 kasus tentang kekerasan pada anak, dan bullying atau perundungan memiliki 41 kasus atau 25, 5 persen dan itu didominasi oleh remaja dan anak-anak. Sekitar $84 \%$ anak-anak di indonsia pernah mengalami kekerasan, namun sebanyak $70 \%$ anak-anak di Indonesia pernah menjadi pelaku kekerasan khususnya di lingkungan sekolah, hal itu merupakan angka yang sangat menghawatirkan khususnya dalam membentuk kepribadian generasi muda.

Sulawesi Utara merupakan kawasan yang ditingali dengan suku, agama, dan budaya yang sangat majemuk. Dengan beragamnya hal tersebut, perilaku-perilaku yang tidak terpuji sangat memungkinkan sering terjadi. Kasus perundungan sudah mulai terjadi dan menyusupi tingkat sekolah dasar tanpa disadari. Perundungan yang terjadi pada anak usia 10 dan 15 tahun yang berujung kematian bukanlah masalah sepele dan harus segera ditelusuri lebih mendalam agar dapat mengetahui akar permasalahan sekaligus cara untuk penanganannya.

Efek negatif yang ditimbulkan akibat perundungan tidak dapat di anggap remeh. Efek berkelanjutan yang dihasilkan sangat mempengaruhi tumbuh kembang anak. Pencapaian keberhasilan dari sisi sosial tidak akan tercapai dan individu yang tidak mencapai tahap perkembangan sesuai dengan umurnya akan menjadi pribadi yang terhambat. Individu yang mengalami perundungan juga cenderung melakukan kembali perilaku tersebut sehingga tidak akan berhenti dan selalu terjadi sampai perilaku itu dapat di singkirkan dari dunia pendidikan.

\section{METODE PENELITIAN}

\section{Desain Penelitian}

Penelitian ini terdiri dari 2 kajian pokok yang berdasar pada latar belakang permasalahan, yaitu tentang perilaku bullying pada tingkatan sekolah dasar dan pola penanganan akan tindakan tersebut. Penelitian ini menggunakan pendekatan kuantitatif deskriptif. Masing-masing variabel menggunakan alat ukur berupa 
skala yang dibuat untuk masing-masing variabel. Hal tersebut dimaksudkan untuk melihat sebab-akibat dari variabel-variabe yang ingin diteliti. Jenis kelamin, tingkatan umur tingkat pendidikan juga akan menjadi batasan-batasan dalam penelitian ketika pengambilan data akan dilakukan oleh peneliti.

\section{Subjek Penelitian}

Penelitian ini di ikuti oleh 75 orang siswa $(\mathrm{N}=75)$, yang merupakan siswa pada kelas 4 sampai 6 Sekolah Dasar dengan mengambil secara keseluruhan siswa yang berada pada rentang kelas tersebut baik siswa laki-laki maupun siswa perempuan.

Subjek penelitian diberikan serangkaian instrument penelitian yang dibagikan secara langsung, kemudian diberikan waktu beberapa menit untuk dapat menyelesaikan serangkaian instrument yang sudah di bagikan tersebut.

\section{Instrumen Penelitian}

Instrument penelitian yang digunakan, merupakan serangkaian instrumen self report, yang diberikan sebanyak satu kali kepada subjek penelitian. Instrument yang dibagikan merupakan instrument yang disusun sendiri oleh peneliti dimana didalam instrument tersebut berisi 21 butir pernyataan yang berfungsi untuk melihat jenis perundungan di sekolah dasar dan penanganan guru terkait perilaku tersebut.. Pilihan jawaban pada butir soal menggunakan skala Likert 4 point $(4=$ sangat sering, $3=$ sering, 2 = tidak pernah, dan 1 = sangat tidak pernah).

\section{Analisis}

Variabel penelitian pada dasaranya adalah segala sesuatu yang berbentuk apa saja yang ditetapkan oleh peneliti untuk diteliti sehingga diperoleh informasi tentang hal tersebut kemudian di tarik kesimpulannya. Dalam penelitian ini variabel yang digunakan merupakan variabel tunggal. Variabel tunggal menurut Hadari Nawawi (1992) adalah variabel yang hanya mengungkapkan variabel untuk di deskripsikan unsur atau faktor-faktor didalam setiap gejala yang termasuk variabel tersebut, maka dalam hal ini, penelitian yang dilakukan merupakan penelitian dengan variabel tunggal.

\section{HASIL DAN PEMBAHASAN}

Dari hasil yang ditemukan untuk melihat pola penanganan bullying pada skolah dasar, terlebih dahulu akan 
dipaparkan model bullying yang seringkali terjadi pada lingkungan sekolah yang dapat dilihat pada tabel I :

Tabel 1. Persentase Perilaku Bullying yang terjadi pada sekolah dasar

\begin{tabular}{lll}
\hline NO & JENIS BULLYING & PERSENTASI \\
\hline 1 & Penindasan Fisik & $48,56 \%$ \\
\hline 2 & Penindasan Verbal & $26,28 \%$ \\
\hline 3 & Tindakan Pengucilan & $12,10 \%$ \\
\hline 4 & $\begin{array}{l}\text { Penindasan Dunia } \\
\text { Maya }\end{array}$ & $5,2 \%$ \\
\hline 5 & Penindasan Seksual & $7,05 \%$ \\
\hline
\end{tabular}

Perilaku perundungan yang terjadi pada sekolah dasar masih di dominasi oleh perundungan fisik $(48,56 \%)$, hal ini memang tergambar dengan lingkungan yang memang sangat rentan akan perkelahian baik sesama desa maupun dengan desa tetangga yang terkadang dipicu oleh permasalahan yang sepele. Menurut Riauskina, dkk (2005) Bentuk kontak langsung pada perundungan antara lain seperti memukul, mendorong, menggigit, menjambak, menendang, mengunci seseorang dalam ruangan, mencubit, mencakar, memeras, dan merusak barang-barang yang dimiliki orang lain.

Kemudian di ikuti perundungan verbal $(26,28 \%)$, dimana dalam hal ini umpatan mapun makian sering sekali terlontar tanpa ada pengawasan berlebih dari tenaga pendidik yang berada di lingkungan sekolah. Kim, J S. (2006) mengemukakan kegiatan yang bertujuan untuk menyakiti seseorang dengan cara menertawakan dengan menjadikannya bahan lelucon, menyapa seseorang dengan nama julukan sehingga akan membuat seseorang manjadi tidak nyaman, sakit hati dan marah.

Tindakan pengucilan $(12,10 \%)$ biasanya terjadi pada kelompok-kelompok bermain maupun dari geng-geng kakak kelas yang dilakukan kepada junior kelasnya agar dapat mengikuti semua kemauan seniornya. Sejiwa (2008) menyatakan bahwa Kegiatan yang bertujuan untuk menolak atau mengeluarkan dan menjauhi seseorang dari kelompok pertemanan atau meninggalkannya dari berbagai hal secara disengaja seperti memfitnah seseorang dengan menceritakan kebohongan tentang seseorang agar orang tersebut di nilai buruk oleh teman-temannya dan memiliki resiko negatif pada mental korban.

Perundungan di dunia maya $(5,2 \%)$ memiliki persentasi yang paling kecil karena di kawasan sekolah maupun di lingkungan bermain masih belum banyak anak sekolah yang udah di izinkan orang tuanya dalam menggunaan gadget. Paparan aksi dan tingkah laku kekerasan yang sering juga ditayangkan oleh televisi dan media elektronik akan mempengaruhi tingkah laku kekerasan anak anak dan remaja. Beberapa 
tahun belakangan ini juga dapat kita lihat dalam media massa liputan6.com (2021) bahwa sangat tindakan perundungan dilakukan sambil direkam dan di tayangkan pada sosial media ataupun dilakukan Live Streaming disaat melakukan adegan perundungan tersebut.

Terakhir yaitu penindasan seksual $(7,05 \%)$ dimana masih banyak yang menjadi korbannya adalah para siswa perempuan dengan jenis tindakan memeluk, memegang tangan, menepuk bokong dan mencium. Bentuk perilaku perundungan dengan pelecehan seksual dikategorikan kedalam bentuk perilaku agresi fisik atau verbal. Barbara (2007) menjelasakan bahwa Penindasan seksual terdiri dari tindakan berulang, berbahaya, dan memalukan yang menargetkan seseorang secara seksual. Contohnya, pemanggilan nama dengan halhal yang berbau seksual, komentar kasar, gerakan vulgar, sentuhan, proposisi seksual, dan materi pornografi.

Anak perempuan sering menjadi sasaran intimidasi seksual baik oleh anak laki-laki maupun anak perempuan lainnya. Anak laki-laki mungkin menyentuhnya dengan lancang, dan membuat komentar kasar tentang tubuh mereka. Sedangkan jika pelakunya perempuan, mungkin memanggil dengan kalimat yang tak pantas serta menghina penampilan atau tubuh si korban.

Konsep perundungan di Indonesia hampir sama dengan konsep perundungan di negara-negara Barat. Bahkan, banyak artikel-artikel yang menulis tentang isu atau perkembangan tindakan perundungan dikutip atau diambil dari beberapa pakar dan berbagai referensi-referensi dari negaranegara Barat. Dalam buku yang berjudul "pencegahan kekerasan terhadap anak di lingkungan pendidikan" menyebutkan bahwa bullying adalah perilaku agresif dan menekan dari seseorang yang lebih dominan terhadap orang yang lebih lemah dimana seorang siswa atau lebih secara terus menerus melakukan tindakan yang menyebabkan siswa lain menderita.

Kekerasan terhadap siswa yang lebih lemah memiliki banyak bentuk. Pertama, secara fisik memukul, menendang, mengambil milik orang lain. Kedua, secara verbal seperti mengolok-olok nama siswa lain, menghina, mengucapkan kata-kata yang menyinggung.Ketiga, secara tidak langsung menyebarkan cerita bohong, mengucilkan, menjadikan siswatertentu sebagai target humor yang menyakitkan, mengirim pesan pendek atau surat yang keji. Mengolok-olok nama merupakan hal yang 
paling umum karena ciri-ciri fisik siswa, suku,etnis, atau warna kulit

Demaray dan malecki (2003) dalam artikelnya menerangkan bahwa tingkah laku perundungan adalah salah satu perilaku negatif yang sering dilakukan oleh orang yang lebih kuat terhadap seseorang yang terlihat lebih lemah atau kurang berkuasa dengan secara berulang dalam tindakannya. Perundung biasanya lebih agresif, memiliki tubuh yang lebih besar dan kekar daripada orang yang menjadi korban, biasanya perundung juga didominasi oleh siswa atau pelajar yang berjenis kelamin laki-laki. Namun diera berkembangnya teknologi yang ada, tidak sedikit dapat kita lihat bahwa pelaku perundungan tidak hanya di dominasi oleh jenis kelamin laki-laki namun juga sudah mulai marak pelaku perundungan dengan jenis kelamin perempuan. Bahkan, tidak sedikit tindakan sadis perundung perempuan kemudian mengupload hasil perundungannya di media sosial.

Perilaku perundungan terkadang hanya di anggap perilaku kenakalan biasa saja dan tidak mendapatkan perhatian yang serius sehingga belum ada keseriusan dari pihak sekolah khususnya guru sehingga tidak ada penanganan yang spesifik tentang perundungan dapat diminimalisir khususnya di dalam lingkungan sekolah. Perundungan tidak bisa dibiarkan tumbuh subur di dalam lingkungan sekolah karena dampak negatif yang dihasilkan akibat perilaku perundungan itu sangat beruntun. Para korban perundungan sebagian besar akan menjadi seorang pelaku perundungan dan sebagian korban lainnya akan memiliki trauma yang berkepanjangan akibat perundungan.

\section{PENUTUP}

Hasil penelitian ini menunjukkan bahwa perilaku Perundungan masih sangat marak terjadi bahkan sampai pada tahap sekolah dasar yang jauh dari perkotaan. Segala bentuk tindakan yang merugikan khususnya untuk tahap perkembangan anak haruslah menjadi perhatian, tidak hanya pendidik tapi juga orang tua. Akibat menyepelekan perilaku perundungan akan memiliki dampak yang buruk dan seperti pada lokasi yang digunakan sebagai tempat penelitian dimana seorang anak akhirnya memilih untuk bunuh diri akibat tidak tahannya perlakuan yang diberikan temannya sehingga korban akhirnya memilih untuk mengakhiri hidupnya.

Edukasi yang baik kepada orang tua maupun pendidik terkait pentingnya kesadaran akan perilaku perundungan anak 
dapat memilimalisir perilaku tersebut. Masih

kurang sadarnya pndidik dalam menanggapi perilaku perundungan sebagai tindakan biasa dan sekedar kenakalan anak-anak pada umumnya akan membuat perundungan selalu subur dalam lingkungan sekolah. Maka sudah sewajarnya seorang pendidik memiliki sensitifitas dalam mendeteksi perilaku perundungan dan memberikan tindakan yang tepat kepada pelaku adalah jalan terbaik.

$$
\text { Lingkungan bermain maupun }
$$
lingkungan keluarga juga harus menjadi lingkungan yang nyaman untuk di gunakan anak-anak dalam bersosialisasi harus cukup terawat, dalam artian, seorang anak yang mampu bersosialisasi dengan teman teman sebayanya tanpa ada perasaan khawatir dan ketakutan akan dapat membentuk mental anak yang sesuai dengan tumbuh kembangnya.

\section{DAFTAR PUSTAKA}

Arina Mufrihah. (2016). Perundungan Reaktif di Sekolah Dasar dan Intervensi Berbasis Nuansa Sekolah. Jurnal Psikologi, Vol. 43 (2), h. 137

Alsa, A. (2007). Pendekatan kuantitatif dan kualitatif serta kombinasinya dalam penelitian psikologi. Yogyakarta: Pustaka Pelajar.
Azwar, S. (2012). Metode penelitian. Yogyakarta: Pustaka Pelajar.

Azwar, S. (2012). Penyusunan skala psikologi (2nd ed.). Yogyakarta: Pustaka Pelajar.

Azwar, S. (2013). Realibilitas dan validitas (4th ed.). Yogyakarta: Pustaka Pelajar.

Coloroso, Barbara. (2007). Stop Bullying: Memutus Rantai Kekerasan Anak dari Prasekolah Hingga SMU. Jakarta: PT Ikrar Mandiriabadi.

D. Olweus. (1994). Bullying at School: Basic Facts and Effects of a School Based Intervention Program. Child Psychology Psychiatry, Vol. 35, h. 71-90.

Houshmand M, dkk (2012). Escaping bullying: The simultaneous impact of individual and unit-level bullying on turnover intentions. Human relation institute. No. 65(7) 901-918

Kim, J.S. (2006). A Study of Personal and Environmental Factors Influencing Bullying. Desertasi (Dipublikasikan). Faculty of Psychology and Education The Ludwig Maximilians Universität Munich: Jerman.

Kristen L. Stives dkk. (2018). Strategies to Combat Bullying: Parental Responses to Bullies. Bystanders, and Victims Youth \& Society $1-19$.

M. K. Demaray \& C. K. Malecki. (2003). Perceptions of the Frequency and Importance of SocialSupport by 
Students Classified as Victims, Bullies, and Bully/Victims in an Urban Middle School. School Psychology Review, Vol. 32, h. 471489.

Riauskina, I. I., Djuwita, R., \& Soesetio, S.R. (2005). Gencet-gencetan dimata siswa siswi kelas 1 SMA: naskah kognitif skenariao \& dampak "gencet-gencetan". Jurnal Psikologi Sosial.

Santrock, J. W. 2002. Life span development: Perkembangan masa hidup(5th ed.) (Achmad Chusairi \& Juda Damanik, Trans.). Jakarta: Erlangga.

Liputan6.com

https://www.liputan6.com/health/rea d/4674379/angka-perundungandaring-pada-anak-meningkatbagaimana-mencegahnya (diakses pada 6 November 2021)

Trevi, Respati. (2012). Sikap Siswa kelas X SMK Y Tangerang Terhadap Bullying. Jurnal Psikologi, Vol. 10 (1), h. 56.

Sansone Randy \& Wiederman W. (2015) Childhood bullying and healthcare adherence in adulthood. International Journal Of Social Psychiatry, Vol. 61(8) 725-728

Schunk, H. D. (2012). Learning Theories and educational perspective : Teoriteori pembelajaran (6th ed.). Yogyakarta : Pustaka Pelajar.

Yayasan Semai Jiwa Amini (Sejiwa). (2008). Bullying Mengatasi Kekerasan di Sekolah dan Lingkungan Sekitar Anak. Jakarta: Grasindo. 